\title{
Neuroprotective effect of tormentic acid against memory impairment and neuro-inflammation in an Alzheimer's disease mouse model
}

\author{
WEIGANG CUI ${ }^{1-3}$, CHUNLI SUN $^{1,2}$, YUQI MA ${ }^{1}$, SONGTAO WANG $^{2}$, XIANWEI WANG $^{3}$ and YINGHUA ZHANG $^{1,2}$ \\ ${ }^{1}$ Department of Human Anatomy; ${ }^{2}$ Xinxiang Key Laboratory of Molecular Neurology; \\ ${ }^{3}$ Henan Key Laboratory of Medical Tissue Regeneration, Xinxiang Medical University, Xinxiang, Henan 453003, P.R. China
}

Received October 19, 2019; Accepted April 21, 2020

DOI: $10.3892 / \mathrm{mmr} .2020 .11154$

\begin{abstract}
Cognitive impairment and neuro-inflammatory responses are the distinctive characteristics of Alzheimer's disease (AD). Tormentic acid (TA) is one of the major active components of Potentilla chinensis and has been demonstrated to have anti-inflammatory properties. However, the potential effects of TA on neuro-inflammatory responses and memory impairment in AD remain unknown. The present study investigated the therapeutic effect of TA on neuro-inflammation, as well as learning and memory impairment in AD mice. In addition, the effects of TA treatment were also examined in a co-culture system of microglia and primary neurons. Intraperitoneal administration of TA attenuated memory deficits in amyloid $\beta$ precursor protein/presenilin 1 transgenic mice, with a marked decrease in amyloid plaque deposition. TA also reduced microglial activation and decreased the secretion of pro-inflammatory factors in AD mice. Furthermore, pre-treatment with TA suppressed the production of pro-inflammatory markers, as well as the nuclear translocation of nuclear factor $-\kappa \mathrm{B}(\mathrm{NF}-\kappa \mathrm{B}) \mathrm{p} 65$ induced by $\mathrm{A} \beta$ exposure in BV2 cells. TA also reduced inhibited neurotoxicity and improved neuron survival in a neuron-microglia co-culture system. Taken together, these findings suggested that TA could attenuate neuro-inflammation and memory impairment, which may be closely associated with regulation of the NF- $\kappa$ B pathway.
\end{abstract}

Correspondence to: Dr Weigang Cui or Professor Yinghua Zhang, Xinxiang Key Laboratory of Molecular Neurology, Xinxiang Medical University, 601 Jinsui Road, Xinxiang, Henan 453003, P.R. China

E-mail: cuiweigang1978@126.com

E-mail: zyhflo2013@163.com

Key words: Alzheimer's disease, tormentic acid, nuclear factor- $\kappa \mathrm{B}$, inflammation, microglia

\section{Introduction}

Alzheimer's disease (AD) is a neurodegenerative disorder characterized by extracellular deposition of $\beta$-amyloid (A $\beta$ ) peptides and intracellular accumulation of hyper-phosphorylated $\tau$ protein, with neuronal loss that leads to progressive cognitive and memory impairment $(1,2)$. Previous studies demonstrated that astrocytes and microglial cells could be activated by the accumulation of $\mathrm{A} \beta$ plaques and that activated microglia released inflammatory molecules and cytokines, leading to neuronal damage that contributed to the pathogenesis of AD (3-5). These previous findings suggested that inflammatory responses could play a key role in the pathology of $\mathrm{AD}$, and that inhibition of inflammation could slow down neurodegeneration in AD.

Previous studies suggested that tormentic acid (TA), a natural triterpene found in the stem bark of medicinal plants, such as Potentilla chinensis (Fig. 1), exhibited a wide range of biological activities, including anticancer, anti-oxidant and anti-inflammatory properties. Yang et al (6) reported that TA inhibited interleukin (IL)- $1 \beta$-induced chondrocyte apoptosis by activating the PI3K/Akt signaling pathway. In addition, TA prevented acetaminophen-induced liver injury by inhibiting oxidative stress and inflammation in mice (7). Moreover, it was previously demonstrated that TA could inhibit $\mathrm{H}_{2} \mathrm{O}_{2}$-induced inflammation and oxidative stress in rat vascular smooth muscle cells via inhibition of the nuclear factor- $\kappa \mathrm{B}(\mathrm{NF}-\kappa \mathrm{B})$ signaling pathway (8). However, the effects of TA on $\mathrm{A} \beta$-induced neuro-inflammation and apoptosis, and its possible neuroprotective function in AD are not fully understood. Therefore, the present study investigated the anti-inflammatory effect of TA both on amyloid $\beta$ precursor protein (APP)/presenilin 1 (PS1) transgenic mice and BV2 microglia cells. Additionally, the possible effects of TA on the $\mathrm{NF}-\kappa \mathrm{B}$ signal pathway were evaluated.

\section{Materials and methods}

Animals. A total of 40 male, 6-month old APP/PS1 transgenic AD mice (weight, $25 \pm 2 \mathrm{~g}$ ), expressing a chimeric mouse/human APP650 cDNA containing the Swedish K670 M and N671L mutations and a mutant human PS1 containing the exon9-deleted 
variant under the control of mouse prion promoter elements were obtained from The Neurobiology and Genetics Laboratory of the Rockefeller University. All mice were bred in-house at The Experimental Animal Center of Xinxiang Medical University, as previously described (9) and kept under a 12-h light-dark cycle at $24^{\circ} \mathrm{C}$, in $50-70 \%$ relative humidity, with ad libitum access to food and water. All animal procedures were carried out in accordance with The National Institutes of Health guidelines and approved by The Animal Ethics Committee of Xinxiang Medical University. For all experiments, animal health and behavior were monitored daily.

Mice were randomly divided into four groups, each receiving $0,1,5$ or $10 \mathrm{mg} / \mathrm{kg}$ TA (Shanghai Winherb Medical S\&T Development Co. Ltd.) in $1 \%$ carboxymethylcellulose (Sigma-Aldrich; Merck KGaA) intraperitoneally. Injections were carried out once daily for 28 consecutive days. At the end of the 28 days, cognitive impairment was assessed using a Morris water maze test. Mice were then sacrificed using an overdose of pentobarbital sodium $(150 \mathrm{mg} / \mathrm{kg})$ at the end of the experiment.

Morris water maze test. The water maze was a circular pool with a $100-\mathrm{cm}$ diameter and $50-\mathrm{cm}$ depth, filled with water. The circular pool was conceptually divided into four quadrants. An escape platform, $10 \mathrm{~cm}$ in diameter, was installed $1 \mathrm{~cm}$ below the surface of the water. The test consisted of two parts, 4 training trials per day for 5 consecutive days, followed by a probe trial. During the training part, each mouse was placed into the four quadrants in a random sequence and allowed to swim for a maximum of $60 \mathrm{sec}$. If the mouse located the platform within $60 \mathrm{sec}$, it was allowed to remain on it for $10 \mathrm{sec}$. Mice that did not find the platform within $60 \mathrm{sec}$ were guided to the platform and allowed to stay on it for $10 \mathrm{sec}$. The probe trial was conducted with the platform removed from the pool and the mice were allowed to swim for $60 \mathrm{sec}$. The time latency swimming speed, distance and number of crossing the platform area were recorded via SMART video tracking system (Ji Liang Instruments, China).

Western blotting assay. Protein extraction from cytosolic and nuclear fractions was performed using a cytosolic/nuclei isolation kit (Sigma-Aldrich; Merck KGaA), as previously described (5). Briefly, brain tissues or cells were homogenized in homogenization buffer (10 mM HEPES; $0.1 \mathrm{mM}$ EDTA; $10 \mathrm{mM} \mathrm{KCl}$; $1 \mathrm{mM}$ DTT; $0.1 \mathrm{mM}$ EGTA; $0.5 \mathrm{mM}$ PMSF; $1 \mathrm{X}$ protease inhibitor cocktail containing aprotinin, bestatin hydrochloride, leupeptin hemisulfate salt and pepstatin A (Sigma-Aldrich; Merck KGaA) for $10 \mathrm{~min}$, then centrifuged at $13,000 \mathrm{x}$ g at $4^{\circ} \mathrm{C}$ for $15 \mathrm{~min}$, and the supernatant was collected. For nuclear protein extracts, the pellets were re-suspended in an equal volume of nuclear extraction buffer (20 mM HEPES; $0.4 \mathrm{M} \mathrm{NaCl} ; 1.5 \mathrm{mM} \mathrm{MgCl}$; 1 mM EGTA; $1 \mathrm{mM}$ DTT; $1 \mathrm{mM}$ EDTA; $0.5 \mathrm{mM}$ PMSF; $1 \mathrm{X}$ protease inhibitor cocktail (Sigma-Aldrich; Merck KGaA) for $30 \mathrm{~min}$, then centrifuged at $13,000 \mathrm{x} \mathrm{g}$ at $4^{\circ} \mathrm{C}$ for $20 \mathrm{~min}$. The supernatants were stored at $-80^{\circ} \mathrm{C}$ for further analysis. Protein concentration was measured via BCA assay (Pierce; Thermo Fisher Scientific, Inc.). For western blots, $30 \mu \mathrm{g}$ protein were loaded on $10-20 \%$ Tricine gels (Thermo Fisher Scientific, Inc.) and electrophoretically transferred on to a $0.22-\mu \mathrm{m}$ PVDF membrane.
Pre-frontal cortex (PFC) and hippocampus (HC) tissues or cells under various treatment conditions were collected and lysed in RIPA buffer (Beyotime Institute of Biotechnology) on ice for $30 \mathrm{~min}$. Protein lysates were centrifuged at 10,000 x g for $30 \mathrm{~min}$ at $4^{\circ} \mathrm{C}$. The supernatant was subjected to western blot analysis. Equal amounts of $30 \mu \mathrm{g}$ protein lysates were loaded on 10-20\% Tricine gels (Thermo Fisher Scientific, Inc.) for SDS-PAGE electrophoresis and then transferred onto a $0.22-\mu \mathrm{m}$ PVDF membrane. The membranes were blocked with 5\% bovine serum albumin (cat no. A7030; Sigma-Aldrich; Merck $\mathrm{KGaA}$ ) for $1 \mathrm{~h}$ at room temperature and then incubated with the following antibodies: Rabbit anti-NF- $\kappa$ B p65 (1:2,000; cat. no. 06-418; EMD Millipore), anti-histone H1 (1:1,000; cat. no. ABE446; EMD Millipore), rabbit anti-phosphorylated inhibitor of $\kappa \mathrm{B}$ kinase $\alpha$ (IKK $\alpha$; 1:800; cat. no. ab38515; Abcam), rabbit anti-IKK $\alpha$ (1:1,000; cat. no. ab32041; Abcam), rabbit anti-phosphorylated inhibitor of nuclear factor $\kappa \mathrm{B} \alpha$ (IкB $\alpha ; 1: 1,000$; cat. no. ab133462; Abcam) and rabbit anti-IкB $\alpha$ (1:1,000; cat. no. ab32518; Abcam). Antibodies against $\beta$-actin (1:1,000; cat. no. ab179467; Abcam) were used as loading controls. Following incubation with horseradish peroxidase conjugated goat anti-rabbit antibodies (1:2,000; cat. no. 111035003; Jackson Immuno Research Laboratories, Inc.) for $1 \mathrm{~h}$ at room temperature. Proteins were detected using the enhanced chemiluminescence (ECL) western blotting substrate (EMD Millipore). The bands were quantified using Image J software (version 1.44p; National Institutes of Health). All western blots were visualized by ECL and normalized to $\beta$-actin or histone $\mathrm{H} 1$ signals.

$A \beta$ ELISA. The PFC and HC tissues were re-suspended in extraction buffer (5 M guanidine; $50 \mathrm{mM}$ Tris- $\mathrm{HCl}$; $\mathrm{pH} 8.0$ ). The homogenates were centrifuged at 20,000 $\mathrm{x} g$ for $1 \mathrm{~h}$ at $4^{\circ} \mathrm{C}$, and supernatant fractions were collected and stored at $-80^{\circ} \mathrm{C}$. The levels of $\mathrm{A} \beta_{1-42}$ were detected using the Human $\mathrm{A} \beta$ ELISA kit (cat. no. KHB3441; Thermo Fisher Scientific, Inc.) according to the manufacturer's instructions and normalized to the total protein content determined via BCA protein assay kit (Pierce; Thermo Fisher Scientific, Inc.). All samples were measured in two independent experiments.

Cytokine assays. Tumor necrosis factor $\alpha$ (TNF $\alpha)$, IL-1 $\beta$ and IL-6 (cat nos. MHSTA50, MLB00C and M6000B, respectively; all R\&D Systems, Inc.) concentrations in PFC, HC and BV2 microglial cell supernatant were measured using ELISA kits according to the manufacturer's instructions. The absorbance at $450 \mathrm{~nm}$ was measured using a microplate reader. All experiments were conducted independently three times.

Quantification of DNA fragmentation. DNA fragmentation in vitro was measured using a Cell Death Detection ELISAPLUS kit (Roche Diagnostics), according to the manufacturer's instructions. Briefly, the tissues or cells were washed with D-Hanks solution. Samples were then lysed with $200 \mu \mathrm{l}$ lysis buffer for $30 \mathrm{~min}$ at $37^{\circ} \mathrm{C}$, and centrifuged at $200 \mathrm{x} \mathrm{g}$ for $10 \mathrm{~min}$ at $4^{\circ} \mathrm{C}$. After centrifugation, $20 \mu 1$ supernatant from each well was transferred toa streptavidin-coated microplate containing anti-DNA-peroxidase and anti-histone-biotin. Nucleosomes from apoptotic cells were captured by the anti-histone-biotin antibody and the anti-DNA-peroxidase, 


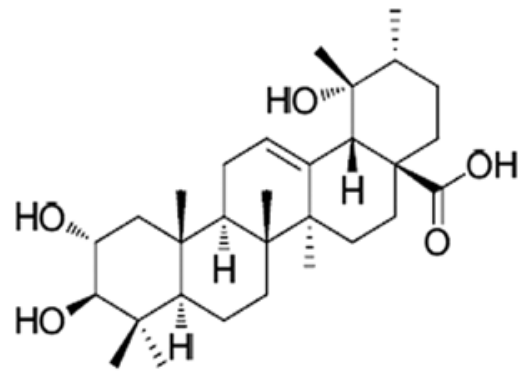

Figure 1. Structure of tormentic acid.

through histone binding to the DNA part of the nucleosomes. After a final wash step was performed to remove unbound antibodies, the amount of peroxidase was quantified using a 2,2'-azino-bis-3-ethylbenzthiazoline-6-sulfonic acid substrate. The absorbance was read at $405 \mathrm{~nm}$ using a microplate reader.

Measurement of caspase-3 activity. Caspase-3 activity was measured using a colorimetric assay kit (Sigma-Aldrich; Merck $\mathrm{KGaA}$ ) according to the manufacturer's protocol. Briefly, tissues or cells were incubated in lysis buffer for $30 \mathrm{~min}$ at $4^{\circ} \mathrm{C}$, and then centrifuged at $16,000 \mathrm{x} \mathrm{g}$ for $10 \mathrm{~min}$ at $4^{\circ} \mathrm{C}$. The supernatant was collected and incubated with the substrate (acetyl-Asp-Glu-Val-Asp-p-nitroanilide) for $90 \mathrm{~min}$ at $37^{\circ} \mathrm{C}$. Caspase-3 activity was measured at $405 \mathrm{~nm}$ spectrophotometrically.

Cell culture. Murine BV2 microglial cells were purchased from The Chinese Academy of Medical Sciences. Cells were maintained in DMEM (Gibco; Thermo Fisher Scientific, Inc.) supplemented with 10\% FBS (Gibco; Thermo Fisher Scientific, Inc.), and incubated in a humidified atmosphere containing 5\% $\mathrm{CO}_{2}$ at $37^{\circ} \mathrm{C}$.

Primary cortical neuronal cells were isolated from the cerebral cortex of 1-dayold pups (P0-P1), as previously described (9). Briefly, cortical fragments were dissected under microscope and dissociated into single cells in $2.5 \mathrm{mg} / \mathrm{ml}$ trypsin for $15 \mathrm{~min}$, and resuspended in DMEM/F12 neurobasal medium (Gibco; Thermo Fisher Scientific, Inc.) supplemented with 10\% FBS (Gibco; Thermo Fisher Scientific, Inc.) and1\% penicillin/streptomycin. Cells were seeded $\left(2 \times 10^{6}\right.$ cells $/ \mathrm{ml}$; $2 \mathrm{ml} /$ well) on poly-D-lysine-coated 6 -well culture polystyrene plates. In total, one-half of the medium volume was removed and replaced with fresh cell culture medium twice per week. Cells were incubated at $37^{\circ} \mathrm{C}$ with $5 \% \mathrm{CO}_{2}$ incubator for 7 days before any assay.

The $\mathrm{A} \beta_{25-35}$ peptide was purchased from the American Peptide Company, Inc. Briefly, $1 \mathrm{mM} \mathrm{A} \beta_{25-35}$ stock solutions were prepared in distilled water to allow peptides to aggregate for 3 days at $37^{\circ} \mathrm{C}(10)$. Cells were treated with TA or vehicle (DMSO) for $8 \mathrm{~h}$, then stimulated with $\mathrm{A} \beta_{25-35}$ for $24 \mathrm{~h}$ after medium removal. Unstimulated cells were used as a negative control.

Cytotoxicity assay in co-culture of microglia and primary cortical neurons. To study the regulation of neuron survival by $A \beta$-stimulated microglia, microglia and primary cortical neurons were co-cultured in 12-well culture plates. Briefly, the
BV2 microglial cells were plated in transwell inserts at a density of $1 \times 10^{4} / \mathrm{cells} / \mathrm{ml}$ for $24 \mathrm{~h}$ before treatment. Subsequently, $10 \mathrm{nM}$ TA was added to the supernatant of BV2 microglial cells for $8 \mathrm{~h}$. The medium was then removed and BV2 microglial cells were cultured in fresh medium with or without $25 \mu \mathrm{M} \mathrm{A} \beta_{25-35}$, and the transwell inserts containing BV2 cells were transferred onto the lower chamber containing cortical neurons to co-culture for another $24 \mathrm{~h}$. Neuronal apoptosis was measured by DNA fragmentation and caspase-3 activity.

MTT assay. Cell viability was measured by an MTT assay as previously described (11).

Immunofluorescence staining. All mice were sacrificed and perfused with $4^{\circ} \mathrm{C} 0.9 \%$ saline followed by $4^{\circ} \mathrm{C} 4 \%$ paraformaldehyde for $4 \mathrm{~h}$. The brains were removed then immersed in $30 \%$ sucrose solution until sunk. Brains were embedded in optimal cutting temperature compound, then were cut on a freezing microtome (Leica Microsystems $\mathrm{GmbH}$ ) to $20-\mu$ m thickness.

For the immunohistochemical staining, brain sections or the cells were blocked with 5\% BSA (cat. no. 810656; Sigma; Merck $\mathrm{KGaA}$ ) for $30 \mathrm{~min}$ at $37^{\circ} \mathrm{C}$, then incubated with mouse anti-A $\beta$ (1:500; cat no. MABN12; Sigma-Aldrich; Merck $\mathrm{KGaA}$ ), rabbit anti-glial fibrillary acidic protein (GFAP; 1:500; cat. no. SAB2107063; Sigma-Aldrich; Merck KGaA), rabbit anti-CD11b (1:300; cat. no. PA5-90724; Chemicon International; Thermo Fisher Scientific, Inc.), and rabbit anti-NF- $\kappa$ B p65 antibody (1:2,000; cat. no. 06-418; EMD Millipore) at $4^{\circ} \mathrm{C}$ overnight. The following day, sections were washed with PBS three times, then incubated with a mixture of Alexa Fluor ${ }^{\circledR} 488$-conjugated donkey anti-rabbit IgG antibody (1:2,000; cat. no. A-21202; Invitrogen; Thermo Fisher Scientific, Inc.) and Alexa Fluor ${ }^{\circledR} 594$-conjugated donkey anti-mouse IgG antibody (1:2,000; cat. no. R37115; Invitrogen; Thermo Fisher Scientific, Inc.) at $37^{\circ} \mathrm{C}$ for $1 \mathrm{~h}$, then stained with $0.1 \%$ DAPI (cat. no. D9542; Sigma-Aldrich; Merck KGaA) at $37^{\circ} \mathrm{C}$ for $5 \mathrm{~min}$. The microscopic images of A $\beta$ immunoreactivity were captured by a computer-controlled Olympus IX71 fluorescent microscope (Olympus Corporation) objective (magnification, $\mathrm{x} 100$ ) and quantified in five fields of view per animal using Image Pro Plus software (Version 6.0; Media Cybernetics, Inc.), with $100-\mu \mathrm{m}$ distance between the sections. All measurements were performed in a blind manner by two investigators. Data are expressed as the percentage of immunoreactive area in the total area and represented as the mean \pm SEM.

Statistical analysis. Data are presented as the mean \pm SEM. Statistical analysis was carried out using SPSS 17.0 software (SPPS, Inc.). The differences between groups were analyzed by one-way ANOVA followed by Bonferroni correction. The escape latencies of the Morris water maze test were calculated using two-way ANOVA for repeated measures, followed by Bonferroni correction for post hoc comparisons. $\mathrm{P}<0.05$ was considered to indicate a statistically significant difference.

\section{Results}

TA suppresses the activation of astroglia and microglia in the PFC and HC. To assess the effect of TA on microglial cells, immunohistochemical analysis was carried out in 

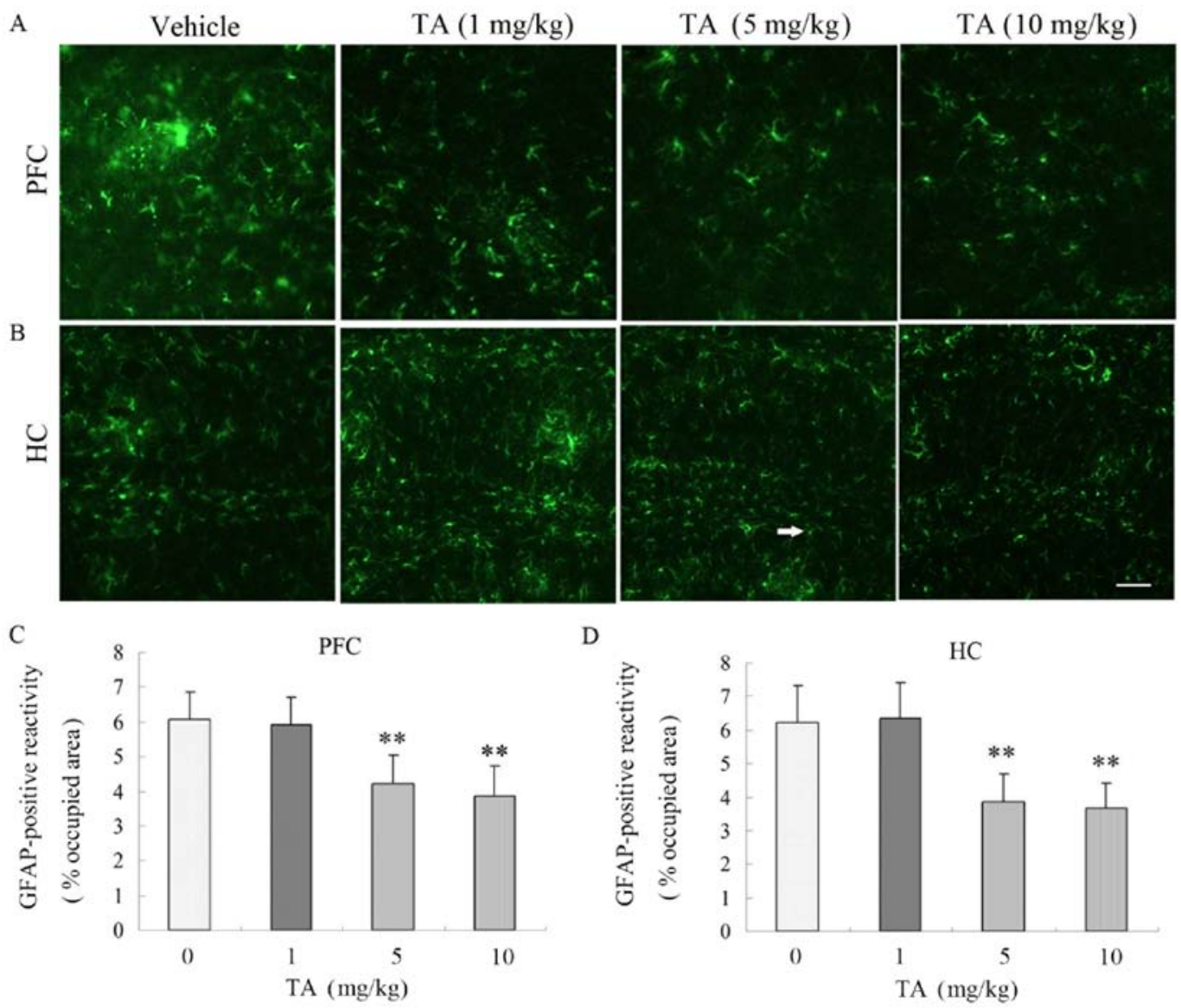

Figure 2. TA treatment decreases the area of GFAP-positive cells in amyloid $\beta$ precursor protein/presenilin 1 transgenic mice. Cells were visualized by immunohistochemical staining and the area of GFAP-positive cells was compared with the vehicle treatment group. (A) GFAP-positive cells in the PFC, indicated by white arrow. (B) GFAP-positive cells in the HC. Scale bar, $40 \mu \mathrm{m}$. (C) Area of GFAP-positive cells in the PFC. (D) Area of GFAP-positive cells in the HC. Data are expressed as the mean \pm SEM for the immunopositive area as $\%$ of total surface area. $n=5$ in each group. ${ }^{* *} \mathrm{P}<0.01$ vs. the vehicle-treated group. TA, tormentic acid; GFAP, glial fibrillary acidic protein; PFC, pre-frontal cortex; HC, hippocampus.

the brain. Treatment with 5 or $10 \mathrm{mg} / \mathrm{kg}$ TA significantly decreased the number of GFAP-positive astrocytes (Fig. 2) and CD11b-positive microglia (Fig. 3) in the PFC and HC, compared with the vehicle-treated group. The levels of inflammatory factors TNF $\alpha$, IL-1 $\beta$ and IL-6 were measured by ELISA. Following treatment with 5 or $10 \mathrm{mg} / \mathrm{kg}$ TA, the expression of TNF $\alpha$, IL-1 $\beta$ and IL- 6 significantly decreased, compared with the vehicle-treated group (Fig. 4).

TA prevents $A \beta$ plaque accumulation in APP/PS1 transgenic mice. The effect of TA on A $\beta$ plaque deposition in APP/PS1 transgenic mice was also assessed. TA treatment was initiated when the mice were 6-months old, and treatment with TA or vehicle lasted for 28 days. Treatment with 5 or $10 \mathrm{mg} / \mathrm{kg}$ TA significantly attenuated the surface area occupied by $\mathrm{A} \beta$ plaque deposition in PFC and $\mathrm{HC}$, compared with the vehicle-treated group, as suggested by immunohistochemical staining (Fig. 5A-D). The levels of $\mathrm{A} \beta_{1-42}$ peptide in the PFC and $\mathrm{HC}$ were also measured by ELISA. Consistent with the immunochemical staining, $A \beta_{1-42}$ levels were significantly reduced in the $\mathrm{PFC}$ and $\mathrm{HC}$ of mice treated with 5 or $10 \mathrm{mg} / \mathrm{kg}$ TA, compared with the vehicle-treated control mice (Fig. 5E and F).

TA treatment ameliorates cognitive deficits and apoptosis in APP/PS1 transgenic AD mice. Learning and memory abilities were evaluated by the Morris water maze test. Compared with the vehicle-treated group, the escape latency of the mice markedly decreased following treatment with 5 or $10 \mathrm{mg} / \mathrm{kg}$ TA (Fig. 6A). During the probe trial, mice treated with TA completed a greater number of target crossings in the target quadrant, compared with the vehicle-treated group (Fig. 6B). However, the mean speed and distance did not differ between the two groups (Fig. 6C and D).

To investigate the potential anti-apoptotic effect of TA, apoptosis was also measured by the extent of DNA fragmentation and the levels of caspase-3 activity. Both parameters significantly decreased after treatment with 5 or $10 \mathrm{mg} / \mathrm{kg}$ TA (Fig. 7).

TA prevents the production of pro-inflammatory factors derived from $B V 2$ microglia. To assess the cytotoxic effect of TA on the microglia, BV2 microglial cells were incubated with different concentrations of TA $(1,5,10,20,50,100$ and $200 \mathrm{nM}$ ) for $8 \mathrm{~h}$, and cell viability was determined via MTT assay. There were no significant differences in cell viability following treatment with TA at concentrations ranging from 1 to $50 \mathrm{nM}$, compared with the control group (Fig. 8A). However, at concentrations of 100 or $200 \mathrm{nM}$, TA significantly decreased cell viability. This demonstrated that high TA concentrations 


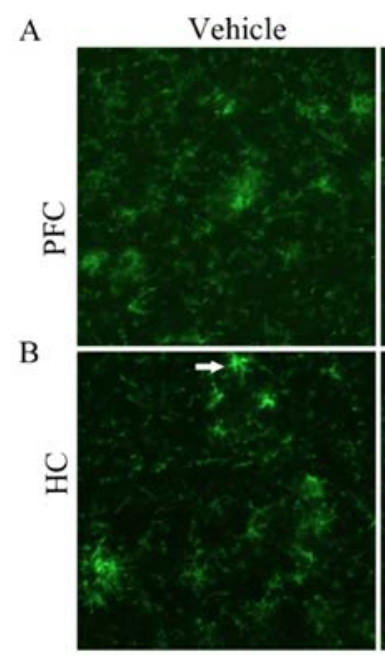

$\mathrm{TA}(1 \mathrm{mg} / \mathrm{kg})$
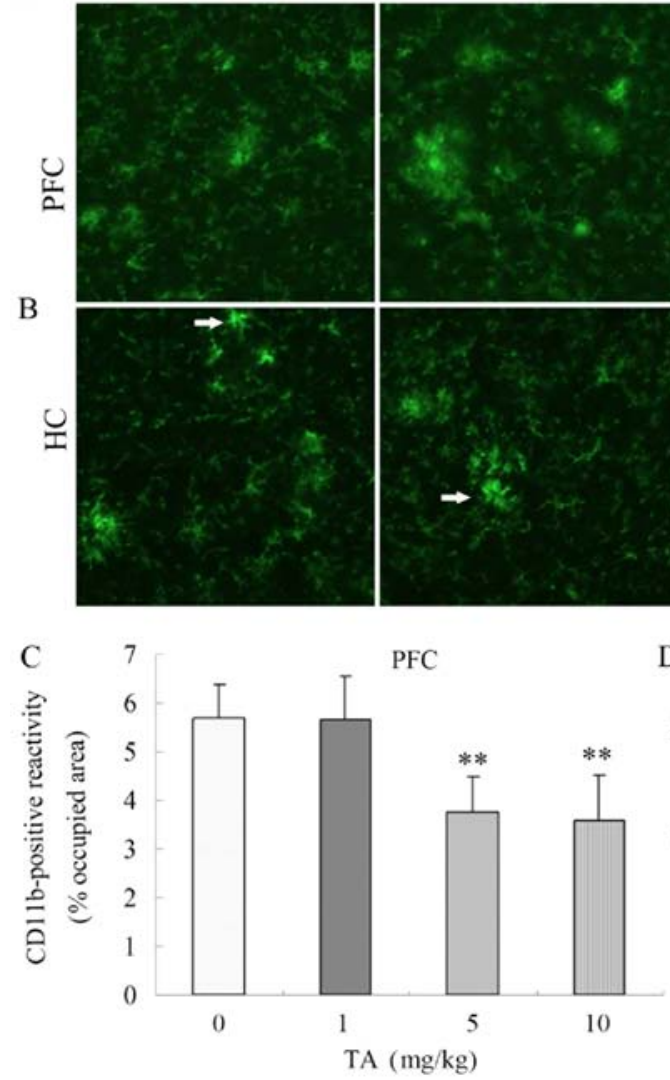

$\mathrm{TA}(5 \mathrm{mg} / \mathrm{kg})$
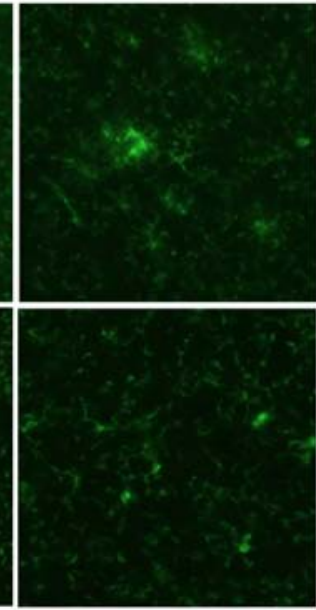

D

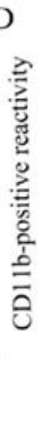

TA ( $10 \mathrm{mg} / \mathrm{kg})$

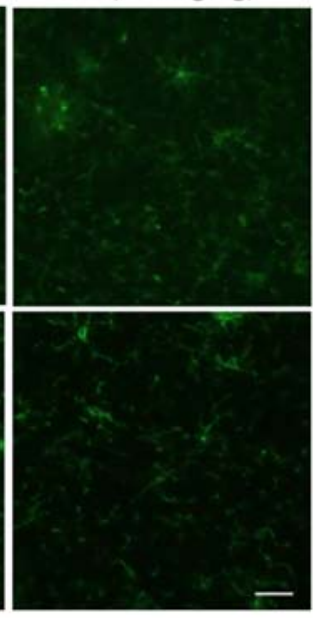

$\mathrm{HC}$

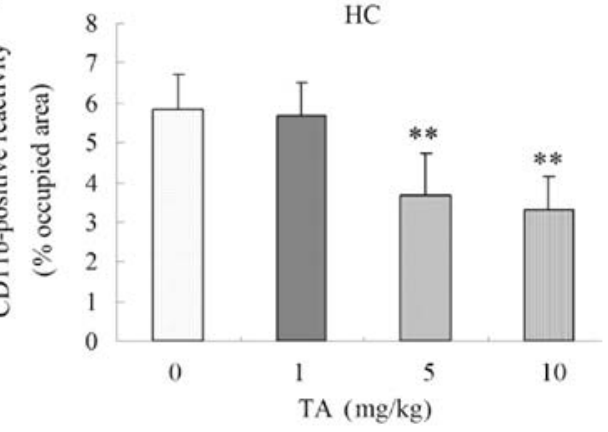

Figure 3. TA treatment decreases the area of CD11b-positive cells in amyloid $\beta$ precursor protein/presenilin 1 transgenic mice. Cells were visualized by immunohistochemical staining and the area of CD11b-positive cells was compared with the vehicle treatment group. (A) CD11b-positive cells in the PFC, indicated by white arrow. (B) CD11b-positive cells in the HC. Scale bar, $40 \mu \mathrm{m}$. (C) Area of CD11b-positive cells in the PFC. (D) Area of CD11b-positive cells in the HC. Data are expressed as the mean \pm SEM for the immunopositive area as $\%$ of the total surface area. $n=5$ in each group. ${ }^{* *} \mathrm{P}<0.01$ vs. the vehicle-treated group. TA, tormentic acid; PFC, pre-frontal cortex; HC, hippocampus.
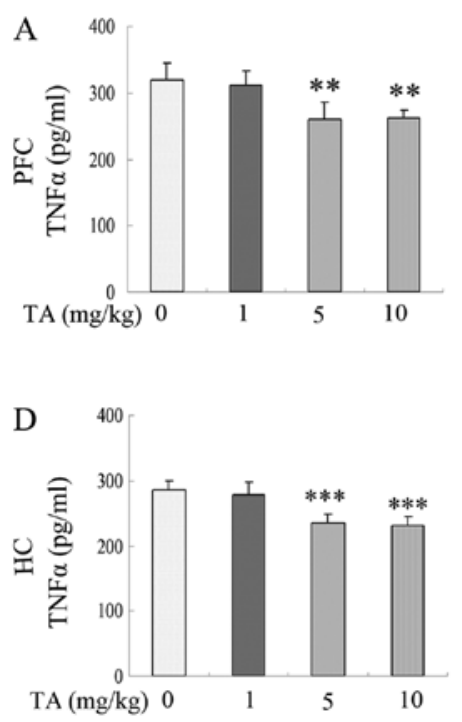

B
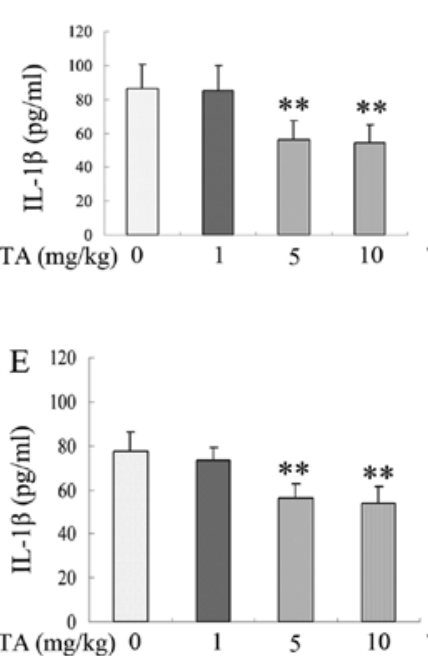

$\mathrm{C}$

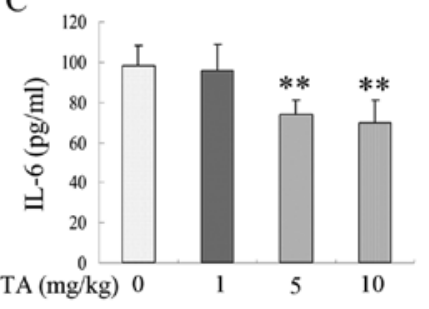

F

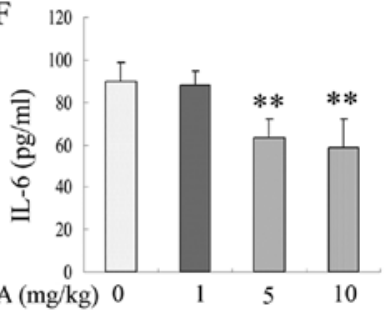

Figure 4. TA treatment decreases the levels of pro-inflammatory factors in APP/PS1 transgenic mice. (A) TNF $\alpha$ level in the PFC. (B) IL-1 $\beta$ level in the PFC. (C) IL-6 level in the PFC. (D) TNF $\alpha$ level in the HC. (E) IL-1 $\beta$ level in the HC. (F) IL-6 level in the HC. $n=5$ in each group. ${ }^{* * *} \mathrm{P}<0.01,{ }^{* * * *} \mathrm{P}<0.001 \mathrm{vs}$. the vehicle-treated group. TA, tormentic acid; APP, amyloid $\beta$ precursor protein; PS1, presenilin 1; PFC, pre-frontal cortex; HC, hippocampus; TNF $\alpha$, tumor necrosis factor $\alpha$; IL, interleukin.

(100 or $200 \mathrm{nM})$ are cytotoxic, whereas lower TA concentrations (1-50 nM) have no cytotoxic effect on BV2 microglial cells.
To further define the dose of TA required for the inhibition of $\mathrm{A} \beta$-induced inflammation, BV2 cells were pre-treated with $25 \mu \mathrm{M} \mathrm{A} \beta_{25-35}$ peptide for $24 \mathrm{~h}$. Treatment with $10 \mathrm{nM}$ TA 

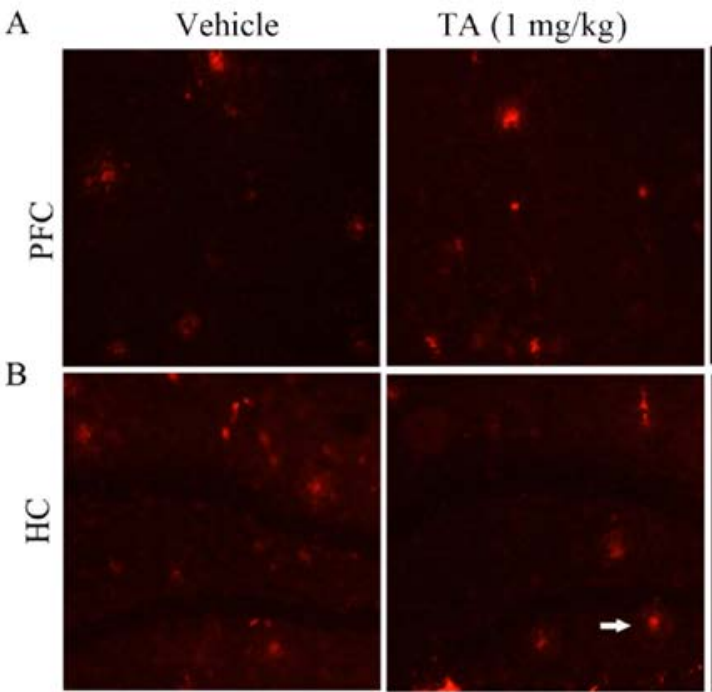

$\mathrm{C}$

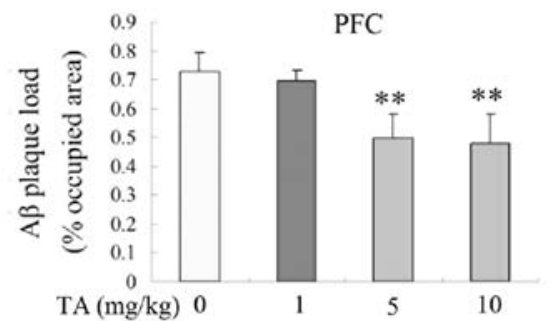

$\mathrm{E}$

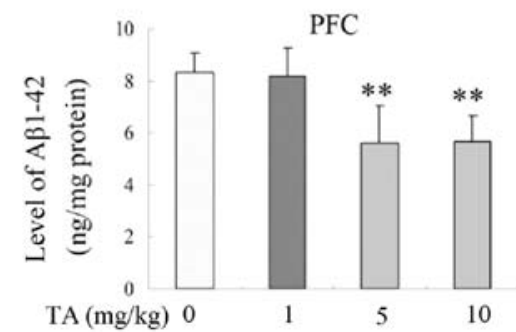

$\mathrm{TA}(5 \mathrm{mg} / \mathrm{kg})$

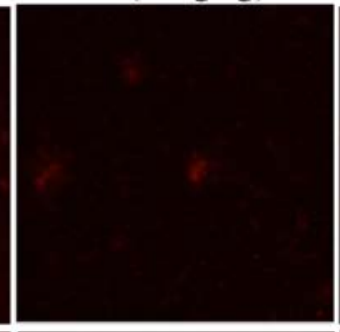

$\mathrm{TA}(10 \mathrm{mg} / \mathrm{kg})$
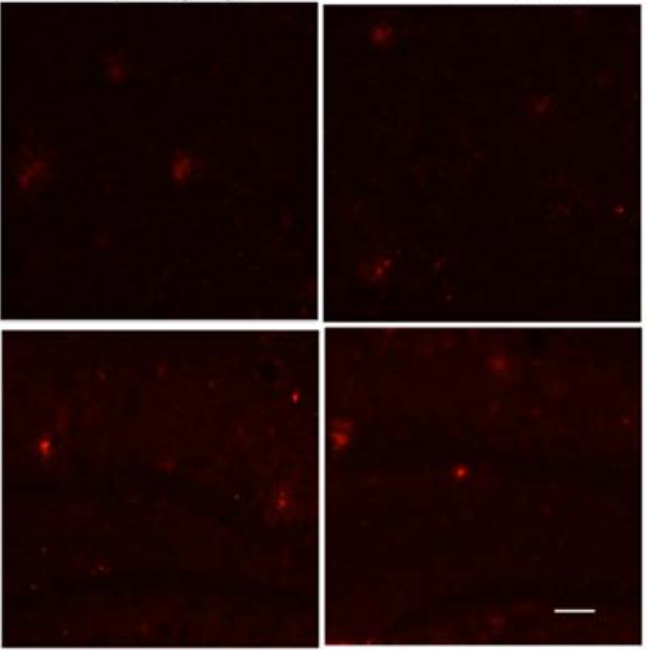

D

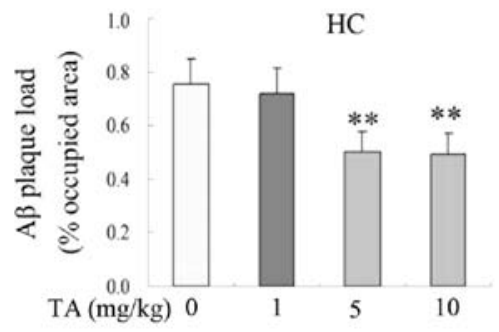

$\mathrm{F}$

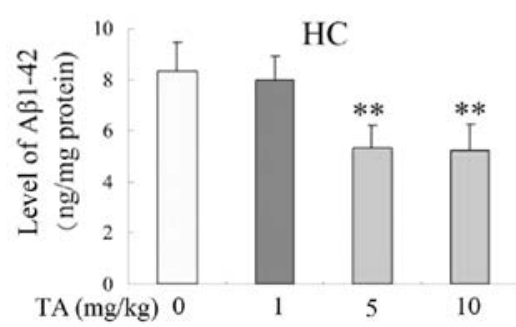

Figure 5. Amyloid $\beta$ precursor protein/presenilin 1 Alzheimer's disease mice treated with TA for 4 weeks exhibit reduced levels of A $\beta$ deposits. (A) Representative images of $\mathrm{A} \beta$ plaque deposition in the PFC. (B) Representative images of A $\beta$ plaque deposition in the HC. A $\beta$ deposits are indicated by white arrow. Scale bar, $100 \mu \mathrm{m}$. (C) A $\beta$ plaque load as $\%$ of total area in the PFC. (D) A $\beta$ plaque load as $\%$ of total area in the HC. (E) A $\beta 1-42$ levels in the PFC. (F) A $\beta_{1-42}$ levels in the HC. $n=5$ in each group. ${ }^{* *} \mathrm{P}<0.01$ vs. the vehicle-treated group. TA, tormentic acid; PFC, pre-frontal cortex; HC, hippocampus; $A \beta$, $\beta$-amyloid.

significantly reduced the levels of TNF $\alpha$ (Fig. 8B). Therefore, $10 \mathrm{nM}$ TA was used in all subsequent experiments.

Microglia can produce inflammatory cytokines after activation (12). To investigate the underlying mechanism of the neuroprotective activity of TA, the potential effect of TA on pro-inflammatory cytokine production, such as TNF $\alpha$, IL-1 $\beta$ and IL-6, in A $\beta$-stimulated BV2 microglia was assessed. BV2 microglia were incubated with $10 \mathrm{nMTA}$ in the presence or absence of $25 \mu \mathrm{M} \mathrm{A} \beta_{25-35}$ peptide. The levels of cytokine in the culture media were measured by an ELISA. The levels of TNF $\alpha$, IL- $1 \beta$ and IL- 6 in the BV 2 microglia supernatant increased following $A \beta$ stimulation. However, these increases in the levels of pro-inflammatory cytokines were significantly inhibited by treatment with TA (Fig. 8C-E).

$N F-\kappa B$ nuclear translocation decreases after TA treatment in response to $A \beta$ stimulation in $B V 2$ microglia cells. The effect of TA on NF- $\kappa$ B p65 nuclear translocation was further analyzed using double immunofluorescence staining and visualization with fluorescent microscopy in BV2 cells.
Fluorescent imaging suggested that nuclear accumulation of $\mathrm{NF}-\kappa \mathrm{B}$ p65 was markedly increased after $A \beta_{25-35}$ stimulation, compared with the control group. However, NF- $\kappa \mathrm{B}$ p65 translocation was abolished by pre-treatment with $10 \mathrm{nM}$ TA (Fig. 9A). In addition, the effect of TA on the levels of cytoplasmic and nuclear NF- $\mathrm{B}$ p65 subunits in all experimental groups was determined by western blot analysis. The levels of NF-kB p65 were significantly increased in the nucleus while the cytoplasmic levels were considerably decreased after $\mathrm{A} \beta_{25-35}$ treatment. Pre-treatment with $10 \mathrm{nM}$ TA significantly inhibited this effect (Fig. 9B and C).

Phosphorylation of IKK and $\mathrm{I} \kappa \mathrm{B} \alpha$ is involved in the activation of the NF- $\kappa \mathrm{B}$ pathway (13). Thus, the levels of the phosphorylated forms of IKK $\alpha$ and I $\kappa \mathrm{B} \alpha$ in BV2 cells in response to $A \beta$ or TA treatments were also investigated. Treatment with $25 \mu \mathrm{M} \mathrm{A} \beta$ for $8 \mathrm{~h}$ induced significantly higher levels of phosphorylated IKK $\alpha$ and I $\kappa \mathrm{B} \alpha$ compared with the control group (Fig. 10A and B). However, these effects were attenuated by pre-treatment with $10 \mathrm{nM}$ TA before exposure to $\mathrm{A} \beta_{25-35}$. Together, these results indicated that TA suppression 

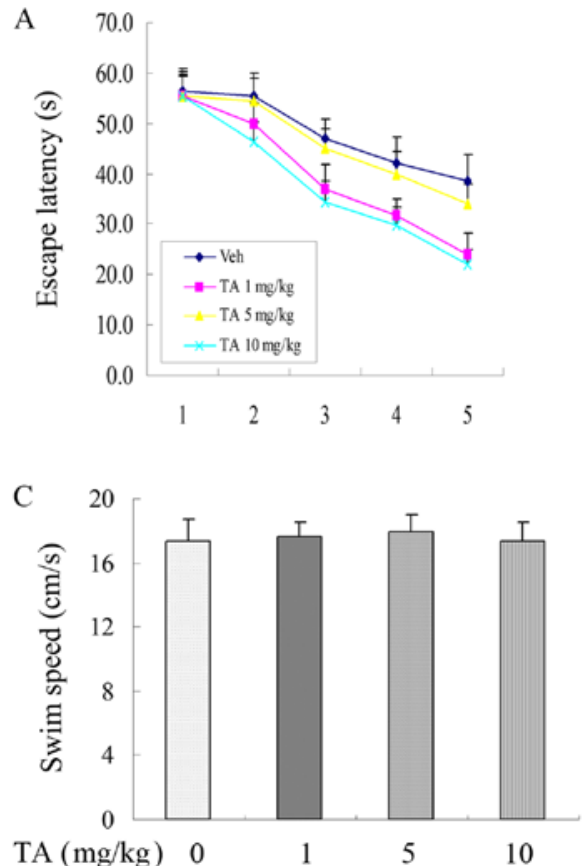
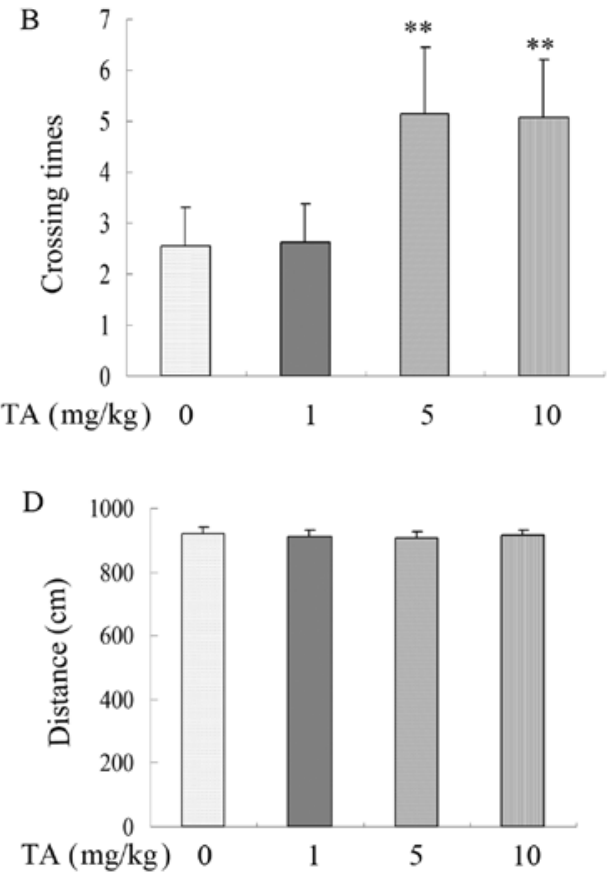

Figure 6. Effects of TA $(0,1,5$ and $10 \mathrm{mg} / \mathrm{kg} ; 4$ weeks) on spatial cognitive deficits in amyloid $\beta$ precursor protein/presenilin 1 transgenic Alzheimer's disease mice are assessed by the Morris water-maze test. (A) Escape latency to reach the submerged platform. (B) Number of platform crossings. (C) Swim speed. (D) Total distance. $\mathrm{n}=10$ in each group. ${ }^{* *} \mathrm{P}<0.01$ vs. the Veh-treated group. TA, tormentic acid; Veh, vehicle.
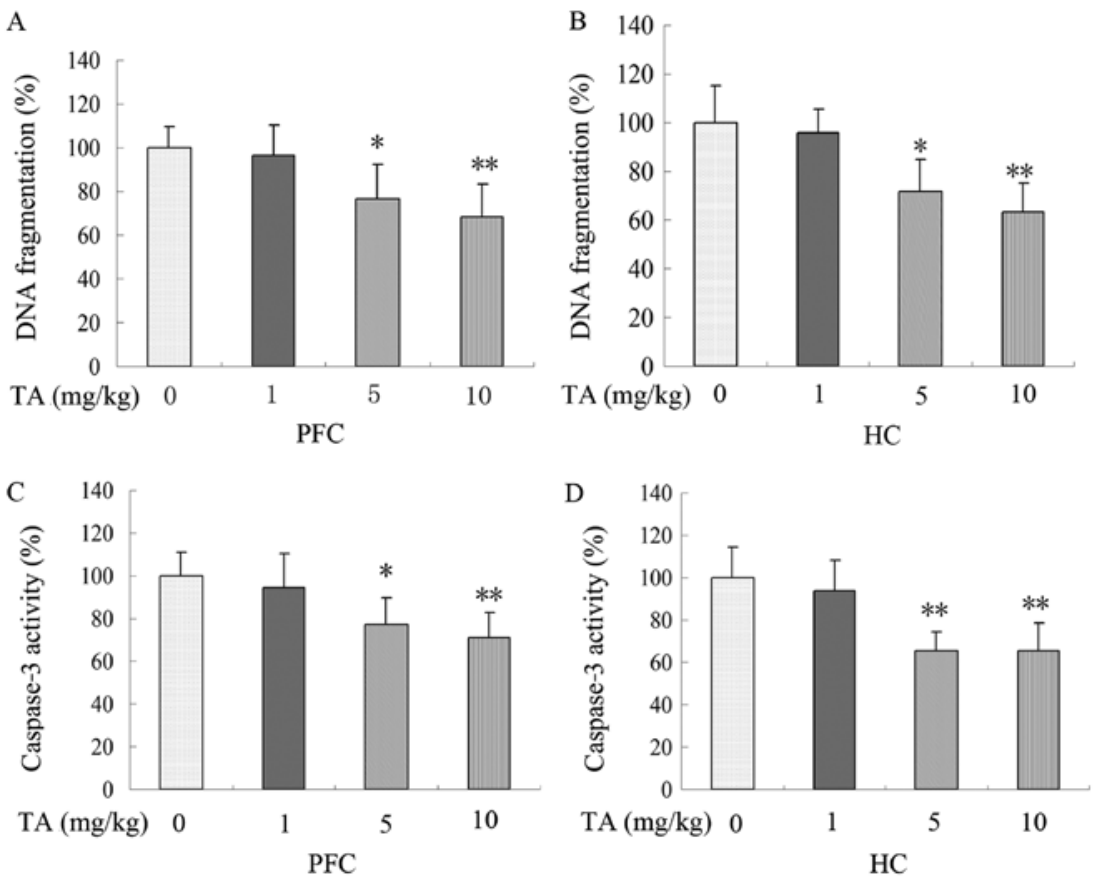

Figure 7. Effects of TA on apoptosis in APP/PS1 transgenic mice. (A) Extent of DNA fragmentation in the PFC. (B) Extent of DNA fragmentation in the HC. (C) Activity of caspase-3 in the PFC. (D) Activity of caspase-3 in HC. Data are presented as the mean $\pm \mathrm{SEM}$. $\mathrm{n}=5$ in each group. $\mathrm{P}<0.05$, ${ }^{* *} \mathrm{P}<0.01$ vs. the control group. TA, tormentic acid; APP, amyloid $\beta$ precursor protein; PS1, presenilin 1; PFC, pre-frontal cortex; HC, hippocampus.

of IL-1 $\beta$ and TNF $\alpha$ expression is most likely associated with inhibition of $\mathrm{NF}-\kappa \mathrm{B}$ activation.

TA attenuates $A \beta$-induced neurotoxicity in primary neuron-microglia co-cultures. To determine whether the apoptotic response was involved in the effect of TA on A $\beta$-induced cell toxicity, the levels of DNA fragmentation and caspase-3 activity in neuron-microglia co-cultures were evaluated after TA treatment. Neuron-microglia co-cultures were treated with $10 \mathrm{nM}$ TA for $8 \mathrm{~h}$, or left untreated as a control. Co-cultures were then incubated with or without $25 \mu \mathrm{M} \mathrm{A} \beta_{25-35}$ for $24 \mathrm{~h}$. Exposure to the $A \beta$ peptide led to a significant increase in the levels of DNA fragmentation and caspase-3 activity. However, after pre-treatment with $10 \mathrm{nM}$ TA, the levels of 


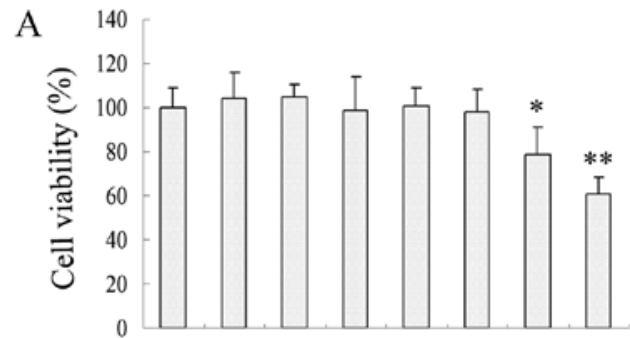

$\mathrm{TA}(\mathrm{nM}) \quad 0 \quad 1 \quad 5 \quad 10 \quad 20 \quad 50 \quad 100 \quad 200$
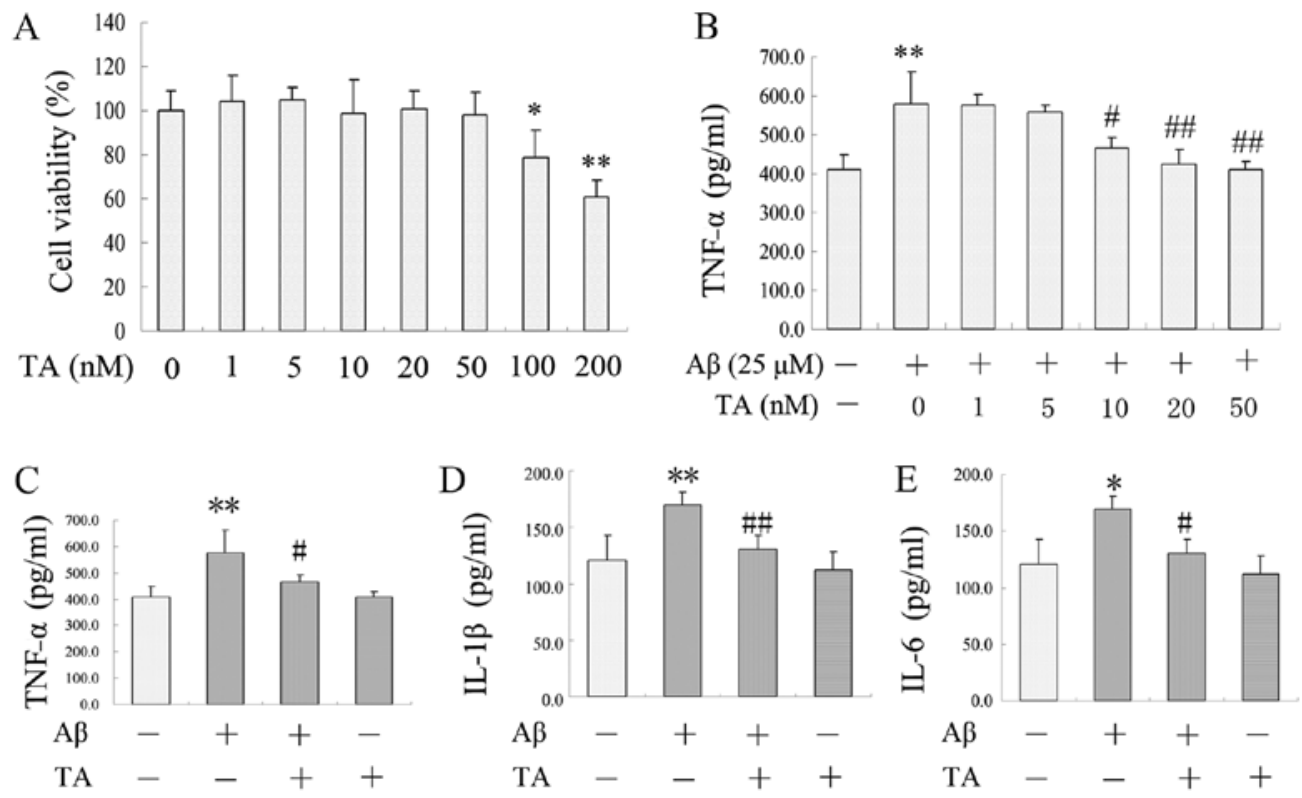

Figure 8. TA inhibits A $\beta$-induced inflammatory cytokine production in vitro. (A) BV2 microglial cells were treated with different concentrations of TA for $24 \mathrm{~h}$, and cell viability was measured by MTT assays. (B) TA dose required for inhibition of A $\beta 1$ - 42 -induced TNF $\alpha$ expression was determined by ELISA. Expressions of (C) TNF $\alpha$, (D) IL-1 $\beta$ and (E) IL-6 in the supernatant were measured using an ELISA kit. Data are presented as the mean \pm SEM. $n=5$ in each group. ${ }^{*} \mathrm{P}<0.05,{ }^{* *} \mathrm{P}<0.01$ vs. the vehicle-treated control group; ${ }^{\#} \mathrm{P}<0.05,{ }^{\# \#} \mathrm{P}<0.01$ vs. the $\mathrm{A} \beta$-treated group. TA, tormentic acid; TNF $\alpha$, tumor necrosis factor $\alpha$; IL, interleukin; $A \beta, \beta$-amyloid.

DNA fragmentation and caspase-3 activity were decreased (Fig. 10C and D), which suggested that the protective effects of TA might be mediated by inhibition of neuronal apoptosis.

\section{Discussion}

Microglial activation caused by $\mathrm{A} \beta$ deposition in the brain is a prominent pathological feature associated with AD (14). Activated microglia release pro-inflammatory cytokines, including IL-1, IL-6 and TNFa (14). Inhibition of microglial activation is thought to be an effective therapy for the treatment of AD (14). In the present study, TA treatment reduced the accumulation of $A \beta$ deposits, successfully attenuated inflammation in APP/PS1 transgenic AD mice and decreased the production of $A \beta$-induced inflammatory cytokines in BV2 microglial cells. Moreover, pre-treatment with TA abolished the translocation of NF- $\mathrm{NB}$ p 65 to the nucleus. Additionally, the effects of TA on the anti-apoptosis function were mitigated by decreased DNA fragmentation and caspase-3 activity in neurons-microglia co-cultures. Altogether, the results of the present study suggested that TA alleviated neuronal injury and inflammation by decreasing pro-inflammatory cytokines production in $\mathrm{AD}$.

A $\beta$ peptides have been demonstrated to induce inflammatory responses (15). Inflammation mediated by glial cells and microglia cells plays a critical role in AD. A $\beta$ deposits are frequently associated with reactive astrocytes and microglia, which induce neuronal injury through the release of pro-inflammatory cytokines in $\operatorname{AD}(16,17)$. A previous study demonstrated that $\mathrm{TA}$ reduced inflammation in $\mathrm{BV} 2$ microglia by activating the liver $\mathrm{X}$ receptor $\alpha$ (18). TA treatment markedly reduced the lipopolysaccharide (LPS)-induced inflammatory response in human gingival fibroblasts (19). In addition, TA significantly decreased Carr-induced inducible nitric oxide synthase (iNOS) and cyclooxygenase-2 (COX-2) expressions in the edematous paw induced by injection of $\lambda$-carrageenin in the plantar side of right hind paw of mice (20). However, a potential therapeutic anti-inflammatory role for TA has not yet been fully demonstrated. To study the effects of TA on the over activated glia cells and microglia in PFC and HC in AD mice, the CD11b-positive microglia cells and GFAP-positive glia cells were detected. TA could significantly decrease the number of GFAP-positive glia cells and CD11b-positive cells and suppress the production of TNF $\alpha$, IL-1 $\beta$ and IL- 6 in the PFC and HC of AD mice, suggesting that TA could represent a novel anti-inflammatory drug for neurodegenerative diseases.

Several previous studies suggested that $A \beta$ induced the production of inflammatory cytokines, $\mathrm{TNF} \alpha-$ and IL-1 $\beta(21,22)$, which are important mediators of the inflammatory response in AD (23). These pro-inflammatory cytokines are thought to be responsible for neural death in AD. In the present study, the inflammation of $\mathrm{AD}$ was mimicked by $\mathrm{A} \beta_{1-42}$ treatment in cultured $\mathrm{BV} 2$ microglia, and the anti-inflammatory effect of TA was measured by observing changes in inflammatory cytokines. The present study demonstrated that $\mathrm{A} \beta$ markedly induced the production of $\mathrm{TNF} \alpha$, IL-1 $\beta$ and IL- 6 , which were significantly suppressed by TA in BV2 microglia. Taken together, the results of the present study suggested that TA could be a promising therapeutic alternative for neurodegenerative diseases caused by microglial activation. However, the mechanism underlying the protective effect of TA in neuronal degeneration remained unclear.

$\mathrm{NF}-\kappa \mathrm{B}$ signaling is central in the control of microglial activation and plays an important role in the production of pro-inflammatory cytokines (24). NF- $\kappa \mathrm{B}$ activation was enhanced and induced the production of IL-1 $\beta$ and TNF $\alpha$ in microglia in response to $A \beta$, through degradation of the inhibitor I $\mathrm{KB} \alpha$ by phosphorylated IKK $\alpha$ (25). The most 
A Control

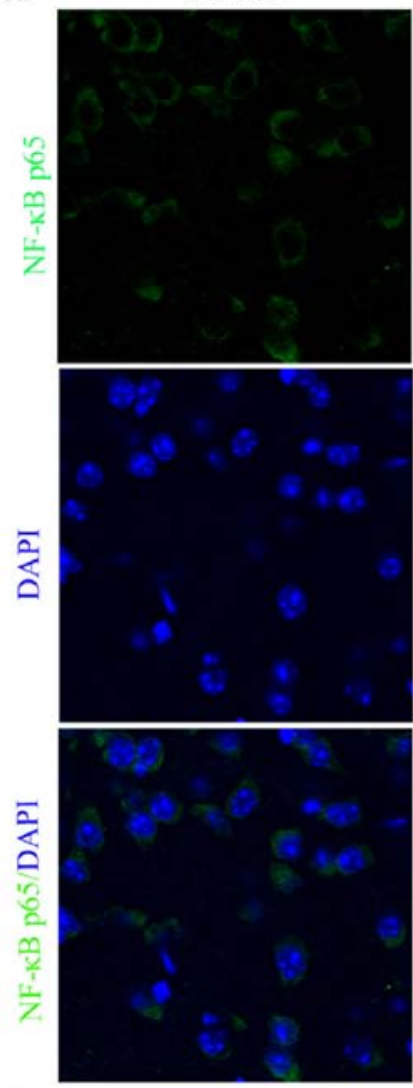

B

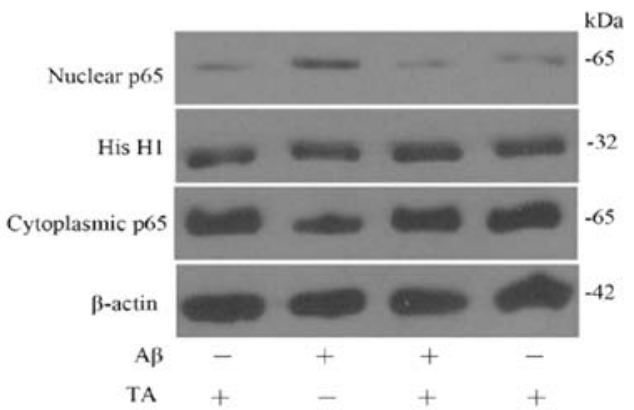

$\mathrm{A} \beta$
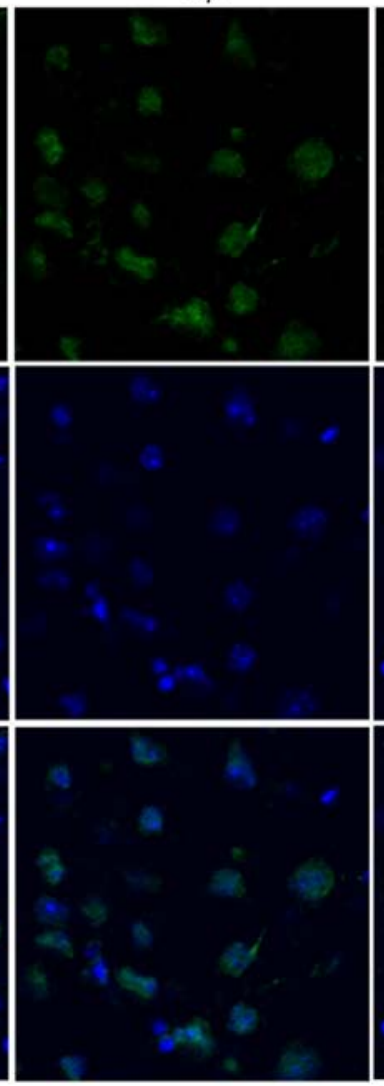

$\mathrm{Da}$
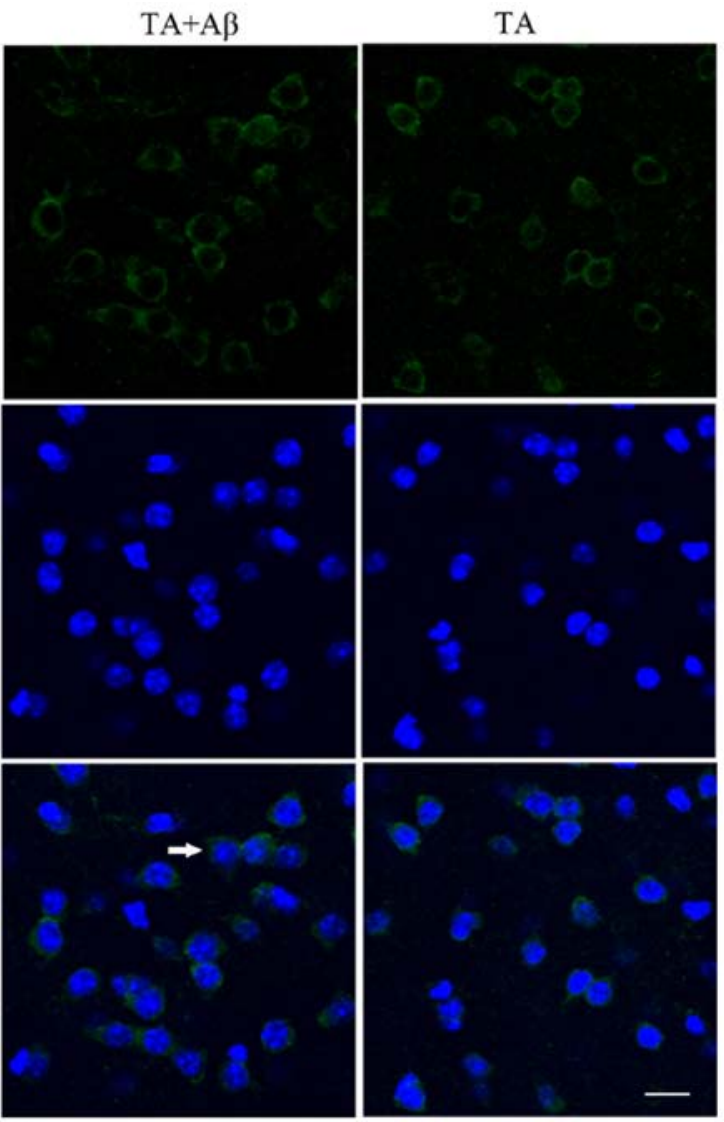

C

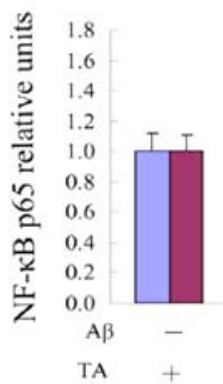

Figure 9. Effect of TA on the NF- $\mathrm{B}$ pathway in A $\beta$-stimulated BV2 microglia. BV2 cells were pre-treated with $10 \mathrm{nM}$ TA for $24 \mathrm{~h}$, then stimulated with $25 \mu \mathrm{M} \mathrm{A} \beta$ for $8 \mathrm{~h}$. (A) Translocation of the NF- $\mathrm{B}$ p 65 subunit was visualized by double immunofluorescence staining. NF- $\kappa \mathrm{B}$ p65 (green), DAPI (blue). $\mathrm{NF}-\kappa \mathrm{B}$ p65-positive cells are indicated by white arrow. Scale bar, $10 \mu \mathrm{m}$. (B) NF- $\mathrm{BB}$ p65 western blots from nuclear and cytoplasmic extracts. (C) Levels of $\mathrm{NF}-\kappa \mathrm{B}$ p65, determined by western blot analysis. His $\mathrm{H} 1$ and $\beta$-actin were used as internal controls. Data are expressed as the mean \pm SEM. $\mathrm{n}=5$ in each group. ${ }^{* *} \mathrm{P}<0.01$ vs. the vehicle-treated control group; ${ }^{\# \#} \mathrm{P}<0.01$ vs. the $\mathrm{A} \beta$-treated group. TA, tormentic acid; $\mathrm{A} \beta, \beta$-amyloid; $\mathrm{NF}$ - $\kappa \mathrm{B}$, nuclear factor $\kappa \mathrm{B} ; \mathrm{His}$, histone.

abundant form of $\mathrm{NF}-\kappa \mathrm{B}$ in the cytoplasm is a heterodimer of p65 and p50 subunits (26). However, under certain pathological conditions, $\mathrm{NF}-\kappa \mathrm{B}$ is activated by exposure to specific inflammatory stimuli (for instance, $A \beta$ ). Activated $N F-\kappa B$ is released and translocates to nucleus, where it can bind to $\kappa \mathrm{B}$ sites and activate transcription of NF- $\kappa \mathrm{B}$-dependent target genes that are important for microglial function (27-29). In the present study, TA decreased the nuclear translocation of $\mathrm{NF}-\kappa \mathrm{B}$ p65. In addition, TA increased the cytoplasmic levels of NF- $\kappa \mathrm{B}$ p65 in BV2 microglia. TA also reversed the expression of phosphorylated IKK $\alpha$ and $\mathrm{I} \kappa \mathrm{B} \alpha$ in BV2 cells following treatment with $A \beta$. The results of the present study are in agreement with a previous study by Jian et al (19) which demonstrated that TA could inhibit LPS-induced inflammatory responses in human gingival fibroblasts through inhibition of the toll like receptor 4-mediated $\mathrm{NF}-\kappa \mathrm{B}$ and
MAPK signaling pathways. Jiang et al (7) demonstrated that TA exerted an anti-inflammatory effect by decreasing iNOS, COX-2, TNF $\alpha$ and IL- $1 \beta$ by inhibiting NF- $\kappa \mathrm{B}$ and MAPK activation. TA also inhibited $\mathrm{H}_{2} \mathrm{O}_{2}$-induced oxidative stress and inflammation by inhibiting NF- $\kappa \mathrm{B}$ signaling in rat vascular smooth muscle cells (8). In addition, TA significantly inhibited the IL- $1 \beta$-induced inflammatory response by suppressing the $\mathrm{NF}-\kappa \mathrm{B}$ signaling pathway in human osteoarthritic chondrocytes (30). Nevertheless, other signaling pathways, such as PI3K/Akt, could also mediate the anti-inflammatory effects of TA in IL- $1 \beta$-induced chondrocyte apoptosis (6). Other TA-induced signaling mediators were not examined in the present study, and further research is required to resolve this issue.

$N F-\kappa B$ signaling has been demonstrated to enhance apoptosis and inhibition of $\mathrm{NF}-\kappa \mathrm{B}$ not only suppresses 


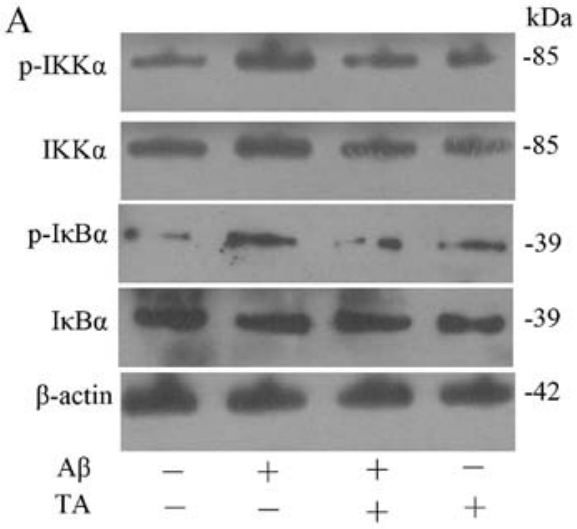

B
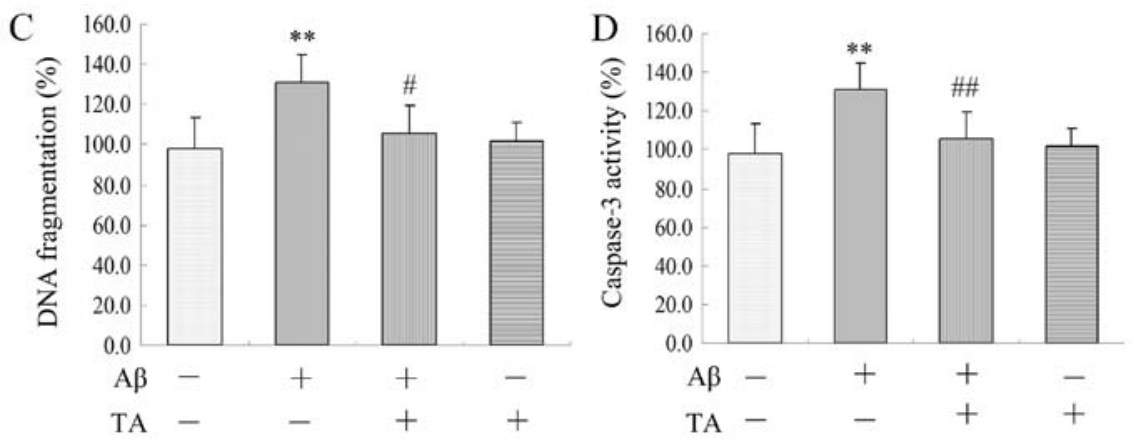

Figure 10. TA suppresses $A \beta$-induced phosphorylation of IKK $\alpha$ and IкB $\alpha$, and apoptosis in BV2 microglia cells. Cells were pre-incubated with or without $10 \mu \mathrm{M}$ of TA for $8 \mathrm{~h}$ prior to A $\beta$ treatment for $24 \mathrm{~h}$. (A and B) Expression levels of cytoplasmic p-IKK $\alpha$ and IкB $\alpha$ were detected by western blotting. TA treatment decreased the level of (C) DNA fragmentation and (D) caspase-3 activity. Data are expressed as the mean \pm SEM. $n=5$ in each group. ${ }^{* *} \mathrm{P}<0.01$, ${ }^{* * * *} \mathrm{P}<0.001$ vs. the vehicle-treated group; ${ }^{\#} \mathrm{P}<0.05,{ }^{\# \#} \mathrm{P}<0.01$ vs. the $\mathrm{A} \beta$-treated group. TA, tormentic acid; $\mathrm{A} \beta, \beta$-amyloid; I $\kappa \mathrm{B}$, inhibitor of nuclear factor $\kappa \mathrm{B}$; IKK, IкB kinase; p, phosphorylated.

inflammatory responses but also prevents apoptosis (31). Neurotoxic neuronal-microglial interactions have been implicated in the development of AD (32). The production of inflammatory cytokines secreted by activated microglia led to neuron apoptosis (33). In the present study, TA decreasedcaspase-3 activity and DNA fragmentation levels in the PFC and $\mathrm{HC}$ of AD mice. Several previous studies demonstrated that in neuron-microglia co-cultures, $\mathrm{A} \beta$-induced neuron degeneration was dependent on the presence of microglia cells $(34,35)$. Thus, inhibition of pro-inflammatory cytokines could offer an effective therapeutic strategy for the prevention of $\mathrm{AD}$ progression. In the present study, $A \beta$-treated neuron-microglia co-cultures were chosen as an in vitro model of $\mathrm{AD}$, as previously described (36). TA significantly decreased the levels of caspase-3 activity and DNA fragmentation in BV2 microglia cells after incubation with $A \beta$. A previous study demonstrated that TA inhibited IL-1 $\beta$-induced chondrocyte apoptosis (6). In addition, TA exerted a protective effect against LPS/D-galactosamine induced fulminant hepatic failure in mice (37). Taken together, these results demonstrated that the anti-apoptotic effect of TA could be attributed to the suppression of pro-inflammatory cytokines, including TNF- $\alpha$, IL-1 $\beta$ and IL- 6 . However, high concentrations of TA (100 and $200 \mathrm{nM}$ ) also reducedBV2 cell viability, suggesting a cytotoxic effect for TA. In agreement with the present results, Loizzo et al (38) described the cytotoxic effects of TA on renal, prostate and melanoma cancer cell lines. Thus, future research should investigate the damage of neurons or microglia cells toxicity caused by TA.
Cognitive impairment and $A \beta$ deposition are the major pathological hallmarks of AD. Indeed, APP/PS1 transgenic $\mathrm{AD}$ mice developed $\mathrm{A} \beta$ plaques at 4 months of age and memory impairment from 6 months of age in a previous study (39). In the present study, at the age of 6 months, APP/PS1 mice were treated with TA for 4 weeks. A Morris water maze test demonstrated that TA improved spatial learning and memory abilities, as reflected by improved escape latency and probe trials of treated mice. A previous study suggested that $A \beta$ levels were associated with neuro-inflammation and neuronal apoptosis (40). Soluble oligomeric $A \beta$ levels and $A \beta$ deposition were increased in the brains of AD and correlated with cognitive dysfunction (41). In the present study, TA administration reduced $\mathrm{A} \beta$ deposition and soluble $A \beta$ levels in the PFC and HC of APP/PS1 mice. These findings suggested that TA could modulate AD pathogenesis. Notably, the present study provided evidence for the beneficial effects of TA in a transgenic mouse model of $\mathrm{A} \beta$ deposition, suggesting that TA may be a candidate for the treatment of AD.

In conclusion, the present study demonstrated that TA suppressed cognitive impairment, neuro-inflammation, microglia activation and A $\beta$ deposition in APP/PS1 transgenic AD mice. Mechanistically, the effects of TA could be mediated by inhibiting the NF- $\mathrm{B}$ signaling pathway.

\section{Acknowledgements}

Not applicable. 


\section{Funding}

The present study was supported by The National Natural Science Foundation of China (grant nos. U1804185, 81873459 and U1804166), The Henan Science and Technology Department Project (grant no. 192102310346) and The Support Project for The Disciplinary Group of Psychology and Neuroscience, Xinxiang Medical University (grant no. 2016PN-KFKT-11).

\section{Availability of data and materials}

The datasets used and/or analyzed during the current study are available from the corresponding author on reasonable request.

\section{Authors' contributions}

WC and $\mathrm{YZ}$ conceived and designed the experiments. YM, CS and XW performed the experiments. WC and SW analyzed the data. WC wrote the manuscript. XW contributed to manuscript revision. All authors read and approved the final manuscript.

\section{Ethics approval and consent to participate}

All animal procedures were carried out in accordance with The National Institutes of Health guidelines and were approved by The Animal Ethics Committee of Xinxiang Medical University.

\section{Patient consent for publication}

Not applicable.

\section{Competing interests}

The authors declare that they have no competing interests.

\section{References}

1. Swanson A, Wolf T, Sitzmann A and Willette AA: Neuroinflammation in Alzheimer's disease: Pleiotropic roles for cytokines and neuronal pentraxins. Behav Brain Res 347: 49-56, 2018.

2. Suwanna N, Thangnipon $\mathrm{W}$ and Soi-Ampornkul R: Neuroprotective effects of diarylpropionitrile against $\beta$-amyloid peptide-induced neurotoxicity in rat cultured cortical neurons. Neurosci Lett 578: 44-49, 2014.

3. Latta-Mahieu M, Elmer B, Bretteville A, Wang Y, Lopez-Grancha M, Goniot P, Moindrot N, Ferrari P, Blanc V, Schussler N, et al: Systemic immune-checkpoint blockade with anti-PD1 antibodies does not alter cerebral amyloid- $\beta$ burden in several amyloid transgenic mouse models. Glia 66: 492-504, 2018.

4. Miron J, Picard C, Frappier J, Dea D, Théroux L and Poirier J: TLR4 gene expression and pro-inflammatory cytokines in Alzheimer's disease and in response to hippocampal deafferentation in rodents. J Alzheimers Dis 63: 1547-1556, 2018.

5. Cui W, Sun Y, Wang Z, Xu C, Peng Y and Li R: Liver X receptor activation attenuates inflammatory response and protects cholinergic neurons in APP/PS1 transgenic mice. Neuroscience 210 200-210, 2012

6. Yang Y, Wang Y, Zhao M, Jia H, Li B and Xing D: Tormentic acid inhibits IL- $1 \beta$-induced chondrocyte apoptosis by activating the PI3K/Akt signaling pathway. Mol Med Rep 17: 4753-4758, 2018.
7. Jiang WP, Huang SS, Matsuda Y, Saito H, Uramaru N, Ho HY, Wu JB and Huang GJ: Protective effects of tormentic acid, a major component of suspension cultures of eriobotrya japonica cells, on acetaminophen-induced hepatotoxicity in mice. Molecules 22: pii: E830, 2017.

8. Wang YL, Sun GY, Zhang Y, He JJ, Zheng S and Lin JN: Tormentic acid inhibits $\mathrm{H} 2 \mathrm{O} 2$-induced oxidative stress and inflammation in rat vascular smooth muscle cells via inhibition of the NF- $\kappa$ B signaling pathway. Mol Med Rep 14: 3559-3564, 2016.

9. Cui W, Sun Y, Wang Z, Xu C, Xu L, Wang F, Chen Z, Peng Y and Li R: Activation of liver $X$ receptor decreases BACE1 expression and activity by reducing membrane cholesterol levels. Neurochem Res 36: 1910-1921, 2011.

10. Casal C, Serratosa J and Tusell JM: Effects of beta-AP peptides on activation of the transcription factor NF-kappaB and in cell proliferation in glial cell cultures. Neurosci Res 48: 315-323, 2004.

11. Chen G, Bower KA, Ma C, Fang S, Thiele CJ and Luo J: Glycogen synthase kinase 3beta (GSK3beta) mediates 6-hydroxydopamine-induced neuronal death. FASEB J 18: 1162-1164, 2004.

12. Gao Y, Zhuang Z, Lu Y, Tao T, Zhou Y, Liu G, Wang H, Zhang D, Wu L, Dai H, et al: Curcumin mitigates neuro-inflammation by modulating microglia polarization through inhibiting TLR4 axis signaling pathway following experimental subarachnoid hemorrhage. Front Neurosci 13: 1223, 2019.

13. Taga M, Minett T, Classey J, Matthews FE, Brayne C, Ince PG, Nicoll JA, Hugon J and Boche D; MRC CFAS: Metaflammasome components in the human brain: A role in dementia with Alzheimer's pathology? Brain Pathol 27: 266-275, 2017.

14. Martínez-Mármol R, Mohannak N, Qian L, Wang T, Gormal RS, Ruitenberg MJ, Vanhaesebroeck B, Coulson EJ and Meunier FA: p1108 PI3-kinase inhibition perturbs APP and TNFa trafficking, reduces plaque burden, dampens neuroinflammation, and prevents cognitive decline in an Alzheimer's disease mouse model. J Neurosci 39: 7976-7991, 2019.

15. Casali BT, Reed-Geaghan EG and Landreth GE: Nuclear receptor agonist-driven modification of inflammation and amyloid pathology enhances and sustains cognitive improvements in a mouse model of Alzheimer's disease. J Neuroinflammation 15: 43, 2018.

16. Yang Z, Kuboyama $\mathrm{T}$ and Tohda $\mathrm{C}$ : Naringenin promotes microglial $M 2$ polarization and $A \beta$ degradation enzyme expression. Phytother Res 33: 1114-1121, 2019.

17. Feng J, Wang JX, Du YH, Liu Y, Zhang W, Chen JF, Liu YJ, Zheng M, Wang KJ and He GQ: Dihydromyricetin inhibits microglial activation and neuroinflammation by suppressing NLRP3 inflammasome activation in APP/PS1 transgenic mice. CNS Neurosci Ther 24: 1207-1218, 2018.

18. Ma A, Wang Y and Zhang Q: Tormentic acid reduces inflammation in BV-2 microglia by activating the liver $\mathrm{X}$ receptor alpha. Neuroscience 287: 9-14, 2015.

19. Jian CX, Li MZ, Zheng WY, He Y, Ren Y, Wu ZM, Fan QS, $\mathrm{Hu}$ YH and Li CJ: Tormentic acid inhibits LPS-induced inflammatory response in human gingival fibroblasts via inhibition of TLR4-mediated NF- $\kappa$ B and MAPK signalling pathway. Arch Oral Biol 60: 1327-1332, 2015.

20. Chang CT, Huang SS, Lin SS, Amagaya S, Ho HY, Hou WC, Shie PH, Wu JB and Huang GJ: Anti-inflammatory activities of tormentic acid from suspension cells of Eriobotrya Japonicaex vivo and in vivo. Food Chem 127: 1131-1137, 2011.

21. Piazza FV, Segabinazi E, de Meireles ALF, Mega F, Spindler CF, Augustin OA, Salvalaggio GDS, Achaval M, Kruse MS, Coirini H, et al: Severe uncontrolled maternal hyperglycemia induces microsomia and neurodevelopment delay accompanied by apoptosis, cellular survival, and neuroinflammatory deregulation in rat offspring hippocampus. Cell Mol Neurobiol 39: 401-414, 2019.

22. Chen Y, Yin M, Cao X, Hu G and Xiao M: Pro- and anti-inflammatory effects of high cholesterol diet on aged brain. Aging Dis 9: 374-390, 2018.

23. Hay M, Polt R, Heien ML, Vanderah TW, Largent-Milnes TM, Rodgers K, Falk T, Bartlett MJ, Doyle KP and Konhilas JP: A novel angiotensin-(1-7) glycosylated mas receptor agonist for treating vascular cognitive impairment and inflammation-related memory dysfunction. J Pharmacol Exp Ther 369: 9-25, 2019.

24. Qin S, Yang C, Huang W, Du S, Mai H, Xiao J and Lü T: Sulforaphane attenuates microglia-mediated neuronal necroptosis through down-regulation of MAPK/NF- $\mathrm{BB}$ signaling pathways in LPS-activated BV-2 microglia. Pharmacol Res 133: 218-235, 2018. 
25. He D, Huang B, Fu S, Li Y, Ran X, Liu Y, Chen G, Liu J and Liu D: Tubeimoside I protects dopaminergic neurons against inflammation-mediated damage in lipopolysaccharide (LPS)-evoked model of Parkinson's disease in rats. Int J Mol Sci 19: pii: E2242, 2018.

26. Lim HS, Kim BY, Kim YJ and Jeong SJ: Phytochemical allylguaiacol exerts a neuroprotective effect on hippocampal cells and ameliorates scopolamine-induced memory impairment in mice. Behav Brain Res 339: 261-268, 2018.

27. Huang Z, Liang N, Damdimopoulos A, Fan R and Treuter E: $\mathrm{G}$ protein pathway suppressor 2 (GPS2) links inflammation and cholesterol efflux by controlling lipopolysaccharide-induced ATP-binding cassette transporter A1 expression in macrophages. FASEB J 33: 1631-1643, 2019.

28. Ou Z, Kong X, Sun X, He X, Zhang L, Gong Z, Huang J, Xu B, Long $\mathrm{D}, \mathrm{Li} \mathrm{J}$, et al: Metformin treatment prevents amyloid plaque deposition and memory impairment in APP/PS1 mice. Brain Behav Immun 69: 351-363, 2018.

29. Simmons LJ, Surles-Zeigler MC, Li Y, Ford GD, Newman GD and Ford BD: Regulation of inflammatory responses by neuregulin-1 in brain ischemia and microglial cells in vitro involves the NF-kappa B pathway. J Neuroinflammation 13: 237, 2016.

30. Yang Y, Wang Y, Wang Y, Zhao M, Jia H, Li B and Xing D: Tormentic acid inhibits IL-1 $\beta$-induced inflammatory response in human osteoarthritic chondrocytes. Inflammation 39: 1151-1159, 2016.

31. Yao Y, Sun F and Lei M: miR-25 inhibits sepsis-induced cardiomyocyte apoptosis by targetting PTEN. Biosci Rep 38: pii: BSR20171511, 2018

32. Yousefi N, Sotoodehnejadnematalahi F, Heshmati-Fakhr N, Sayyah M, Hoseini M, Ghassemi S, Aliakbari S and Pourbadie HG: Prestimulation of microglia through TLR4 pathway promotes interferon beta expression in a rat model of Alzheimer's disease. J Mol Neurosci 67: 495-503, 2019

33. Gabbouj S, Natunen T, Koivisto H, Jokivarsi $K$, Takalo M, Marttinen M, Wittrahm R, Kemppainen S, Naderi R, Posado-Fernandez A, et al: Intranasal insulin activates Akt2 signaling pathway in the hippocampus of wild-type but not in APP/PS1 Alzheimer model mice. Neurobiol Aging 75: 98-108, 2019

34. Tible M, Mouton LF, Schmitt J, Giralt A, Farid K, Thomasseau S Gourmaud S, Paquet C, Rondi RL, Meurs E, et al: PKR knockout in the 5xFAD model of Alzheimer's disease reveals beneficial effects on spatial memory and brain lesions. Aging Cell 18 : e12887, 2019.
35. Yin P, Wang S, Wei Y, Wang X, Zhang J, Yin X, Feng J and Zhu M: Maresin1 decreased microglial chemotaxis and ameliorated inflammation induced by amyloid- $\beta 42$ in neuron-microglia co-culture models. J Alzheimers Dis 73: 503-515, 2020.

36. Basso L, Lapointe TK, Iftinca M, Marsters C, Hollenberg MD, Kurrasch DM and Altier C: Granulocyte-colony-stimulating factor (G-CSF) signaling in spinal microglia drives visceral sensitization following colitis. Proc Natl Acad Sci USA 114: 11235-11240, 2017.

37. Lin X, Zhang S, Huang R, Tan S, Liang S, Wu X, Zhuo L and Huang Q: Protective effect of tormentic acid from Potentilla chinensis against lipopolysaccharide/D-galactosamine induced fulminant hepatic failure in mice. Int Immunopharmacol 19: 365-372, 2014.

38. Loizzo MR, Bonesi M, Passalacqua NG, Saab A, Menichini F and Tundis R: Antiproliferative activities on renal, prostate and melanoma cancer cell lines of Sarcopoterium spinosum aerial parts and its major constituent tormentic acid. Anticancer Agents Med Chem 13: 768-776, 2013.

39. Cui W, Tao J, Wang Z, Ren M, Zhang Y, Sun Y, Peng Y and Li R: Neuregulin1beta1 antagonizes apoptosis via ErbB4-dependent activation of PI3-kinase/Akt in APP/PS1 transgenic mice. Neurochem Res 38: 2237-2246, 2013.

40. Snow AD, Castillo GM, Nguyen BP, Choi PY, Cummings JA, Cam J, Hu Q, Lake T, Pan W, Kastin AJ, et al: The Amazon rain forest plant Uncaria tomentosa (cat's claw) and its specific proanthocyanidin constituents are potent inhibitors and reducers of both brain plaques and tangles. Sci Rep 9: 561, 2019.

41. Logue MW, Panizzon MS, Elman JA, Gillespie NA, Hatton SN, Gustavson DE, Andreassen OA, Dale AM, Franz CE, Lyons MJ, et al: Use of an Alzheimer's disease polygenic risk score to identify mild cognitive impairment in adults in their $50 \mathrm{~s}$. Mol Psychiatry 24: 421-430, 2019.

This work is licensed under a Creative Commons Attribution-NonCommercial-NoDerivatives 4.0 International (CC BY-NC-ND 4.0) License. 